\title{
Simultaneous bilateral peritonsillar abscess in an adolescent
}

Równoczesny obustronny ropień okołomigdałkowy u młodej pacjentki

\author{
'Department of Otorhinolaryngology, Hospital Tuanku Ja'afar, Jalan Rasah, 70300 Seremban, Negeri Sembilan, Malaysia \\ ${ }^{2}$ Department of Otorhinolaryngology, Faculty of Medicine, University of Malaya, Jalan Universiti, 50603 Kuala Lumpur, Malaysia \\ Correspondence: Jeyasakthy Saniasiaya, MD, MMED (ORL-HNS), FEBEORL-HNS, Department of Otorhinolaryngology, Faculty of Medicine, University of Malaya, Jalan Universiti, 50603 Kuala Lumpur, \\ Malaysia, e-mail: shakthy_18@yahoo.com
}

\begin{abstract}
Aim of the study: The aim of this case report is to emphasise the importance of meticulous history-taking and examination, and to raise the awareness of various possibilities of diagnosis and management. Unilateral peritonsillar abscess is a common complication of acute bacterial tonsillitis. However, bilateral peritonsillar abscess is considered rare, and only a meagre number of cases has been reported to date in the English medical literature. The challenging part involved in the diagnosis of bilateral peritonsillar abscess is the absence of common physical findings of unilateral peritonsillar abscess. Case report: We present a case of a teenage girl who presented with a history of worsening sore throat, odynophagia and muffled voice, which turned out to be bilateral peritonsillar abscess. Oropharyngeal examination revealed bilateral peritonsillar fullness, and pus was aspirated bilaterally. The patient underwent bilateral peritonsillar incision and drainage, and was discharged well after a few days, with no recurrence. Bilateral peritonsillar abscess can present with usual symptoms, but physical findings may vary. Conclusion: Proper history-taking and meticulous physical examination may direct the physician towards correct diagnosis, and an imaging evaluation is warranted if in doubt, so as to avoid unwanted perilous complications.
\end{abstract}

Keywords: peritonsillar abscess, bilateral, acute tonsillitis, tonsillectomy, neck abscess

Streszczenie Cel pracy: Celem przedstawienia przypadku jest podkreślenie znaczenia skrupulatnego wywiadu i badania przedmiotowego oraz zwiększenie świadomości co do różnych możliwości diagnozy i postępowania u pacjentów z obustronnym ropniem okołomigdałkowym. Jednostronny ropień okołomigdałkowy to częste powikłanie ostrego bakteryjnego zapalenia migdałków, natomiast obustronny ropień okołomigdałkowy występuje rzadko, a w anglojęzycznej literaturze medycznej dostępnych jest zaledwie kilka opisów takich przypadków. Wyzwaniem diagnostycznym w obustronnym ropniu okołomigdałkowym jest często stwierdzany brak objawów przedmiotowych typowych dla jednostronnego ropnia okołomigdałkowego. Opis przypadku: Autorzy przedstawiają przypadek młodej kobiety, u której w wywiadzie odnotowano nasilający się ból gardła, bolesność przy przełykaniu i chrapliwy głos. Ustalono rozpoznanie obustronnego ropnia okołomigdałkowego. W badaniu jamy ustnej i gardła stwierdzono obustronne powiększenie przestrzeni okołomigdałkowych, z których aspirowano treść ropną. U pacjentki wykonano obustronne nacięcie okolic ropni i założono drenaż. Po kilku dniach chora została wypisana do domu, bez późniejszych nawrotów choroby. Obustronny ropień okołomigdałkowy może dawać typowe objawy podmiotowe, natomiast objawy przedmiotowe mogą być zróżnicowane. Wnioski: Prawidłowe zbieranie wywiadu i skrupulatne badanie przedmiotowe może ukierunkować lekarza na prawidłowe rozpoznanie. W razie wątpliwości wskazana jest ocena obrazowa, aby uniknąć niepożądanych, niebezpiecznych powikłań.

Słowa kluczowe: ropień okołomigdałkowy, obustronny, ostre zapalenie migdałków, tonsilektomia, ropień szyi 


\section{INTRODUCTION}

$\mathrm{P}$ eritonsillar abscess (PTA), also known as quinsy, is a disease which occurs when pus accumulates in the peritonsillar space - a potential space bounded medially by the palatine tonsillar capsule, laterally by the superior constrictor muscle, anteriorly by the palatoglossal muscle, and posteriorly by the palatopharyngeal muscle. The condition is usually unilateral, and it is considered to be the most common complication following acute tonsillitis ${ }^{(1)}$. Despite countless theories which have been proposed to explain the pathophysiology of this entity, it is usually assumed that the disease occurs following blockage of Weber's gland, a minor salivary gland located within the peritonsillar space, causing peritonsillitis and ultimately $\mathrm{PTA}^{(2)}$. Ascending infection from infected crypts within the tonsils is another one ${ }^{(2)}$. The occurrence of bilateral PTA, albeit rarely, has been reported ${ }^{(3,4)}$. Herein, we present our case of bilateral PTA which occurred simultaneously in a young girl, and was successfully treated.

\section{CASE REPORT}

A previously healthy19-year-old girl presented with a fourday history of worsening sore throat and odynophagia. Further history revealed that sore throat was accompanied by low-grade fever, muffled voice and trismus. There was, however, no difficulty in breathing, and no neck swelling, obstructive airway or constitutional symptoms. According to the patient, this was her first episode, and there were no family members with similar complaints. In addition to that, the patient is a non-smoker with no high-risk behaviours. No recurrent nasal or otological symptoms were revealed.

On physical examination, the patient appeared lethargic and dehydrated. There was no audible stridor, and she was not in respiratory distress. The vital signs were stable. There was, however, limited mouth opening, which made intraoral examination difficult. The oral cavity revealed a coated tongue with fair dental hygiene. Oropharyngeal examination showed bulging over the bilateral peritonsillar region, with evidence of pus draining from the left peritonsillar region (Fig. 1). There was no deviation of the uvula, bulging of the posterior pharyngeal wall or medialisation of the lateral pharyngeal wall.

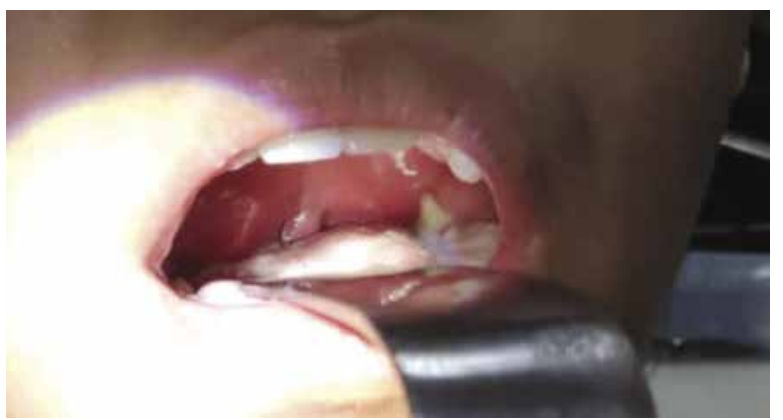

Fig. 1. Bulging seen over the bilateral peritonsillar region, with evidence of pus draining from the left peritonsillar region
Aspiration was performed over the most fluctuant site of the peritonsillar region using a 25 -gauge needle, revealing the presence of thick pus. The patient's consent was obtained, and incision and drainage of the bilateral peritonsillar region was done under local anaesthesia, yielding $5 \mathrm{cc}$ of pus over the right and $3 \mathrm{cc}$ of pus over the left side, which was sent for culture and sensitivity and acid-fast bacilli smear. The patient was admitted and started on intravenous C-penicillin 2.5 mega unit four times daily along with maintenance intravenous normal saline and antiseptic gargle. The patient's complete blood count showed marked leucocytosis with neutrophil $(76.8 \%)$ predominance. She was then admitted to ward for IV C. The drainage site was re-opened daily, with a significant reduction noted after day three (Fig. 2).

The patient was subsequently discharged after three days with oral penicillin $\mathrm{V}$ and the gargle. At her follow-up after two weeks, the patient was completely recovered, and no recurrence was noted after six months of follow-up.

\section{DISCUSSION}

Bilateral PTA was first reported by Grahne ${ }^{(5)}$ in an article published in 1958. The average incidence of this entity has been postulated to be between 4.8 and $4.9 \%{ }^{(6)}$. PTA is seen more commonly among men than women, with a ratio of $2: 1^{(7)}$, with average age of 20 to 40 years of age ${ }^{(2,3)}$. Cases of bilateral PTA may be underreported due to the role of early antibiotics. Our hypothesis is that our patient had untreated bilateral acute tonsillitis which progressed into bilateral peritonsillitis, and subsequently evolved into bilateral PTA. Unilateral PTA commonly presents with classical symptoms of trismus, odynophagia and "hot potato" voice, with intraoral examination revealing an asymmetrical palatine tonsil with deviated uvula. This classical presentation may not be found in bilateral cases, as their presentation tends to vary. Nevertheless, the presence of trismus has been claimed to

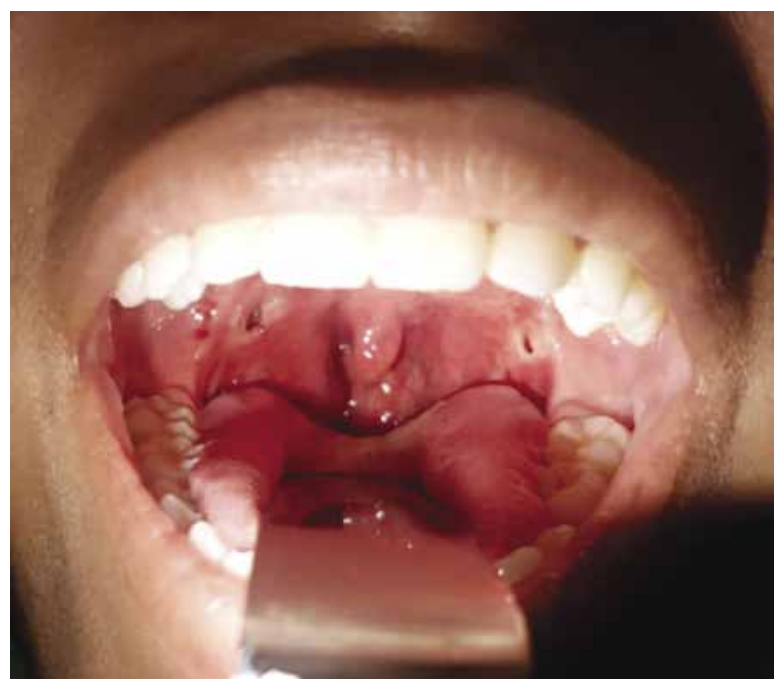

Fig. 2. Post incision and drainage of bilateral peritonsillar abscess 
be suggestive of double PTA ${ }^{(8)}$. It is noteworthy that non-relenting fever despite successful drainage in unilateral PTA should raise a suspicion of double abscess ${ }^{(9)}$. Bilateral PTA may also present with acute airway emergency if not identified early, as it can spread into other potential spaces, mainly into the parapharyngeal and retropharyngeal space, leading to airway obstruction.

A risk factor for this entity is similar to unilateral PTA, i.e. smoking. Gingival mucosa atrophy, and alteration of oral cavity flora are caused by nicotine and other chemical substances in cigarette smoke, which leads to decreased oral cavity immunity.

Bilateral peritonsillar bulge may masquerade other diseases including acute tonsillitis, infectious mononucleosis, lymphoma, minor salivary gland tumour, HIV-related infections, and retropharyngeal abscess. When in doubt, it is imperative for the clinician to perform an imaging examination as a guide. Contrast-enhanced computed tomography can reveal the presence of a collection and also its extension.

Nevertheless, the best readily available diagnostic procedure remains bedside needle aspiration which instantaneously reveals the presence of abscess. Caution should be taken so as not to proceed too deep, as the internal carotid artery can be more medialised in some individuals.

Despite the never-ending debate on the best treatment of PTA, most authors believe that the mainstay of treatment is aspiration and subsequently drainage supplemented with intravenous antibiotics. The practice of "hot tonsillectomy" or tonsillectomy à chaud, was the preferred modality previously, as free drainage was obtained. However, many authors are reluctant to use this procedure owing to the high risk of devastating primary and secondary haemorrhage. Kieff et al. ${ }^{(10)}$ conducted a study to compare the efficacy of intravenous penicillin versus broad-spectrum antibiotics, and concluded that intravenous penicillin remained an excellent choice of antibiotic amongst PTA patients following incision and drainage. Accordingly, our patient was successfully treated with intravenous penicillin post drainage. Multiple complications may arise if prompt treatment is delayed, including the spread of infection to the parapharyngeal or retropharyngeal spaces, and leading to mediastinitis, upper airway obstruction and, rarely, pseudoaneurysm of the carotid artery ${ }^{(1,8)}$.

\section{CONCLUSION}

Bilateral PTA is a rare disease which often presents with non-classical findings, unlike unilateral PTA. Bedside needle aspiration is the best readily available test to confirm the diagnosis, followed by drainage. Early diagnosis and prompt treatment are essential to prevent further serious complications such as deep neck abscess and mediastinitis ${ }^{(11)}$.

\section{Conflict of interest}

\section{References}

1. Aldakhail AA, Khan MI: A retrospective study of peritonsillar abscess in Riyadh Medical Complex [corrected]. Saudi Med J 2006; 27: 1217-1221.

2. Papacharalampous GX, Vlastarakos PV, Kotsis G et al.: Bilateral peritonsillar abscesses: a case presentation and review of the current literature with regard to the controversies in diagnosis and treatment. Case Rep Med 2011; 2011: 981924.

3. Pham V, Gungor A: Bilateral peritonsillar abscess: case report and literature review. Am J Otolaryngol 2012; 33: 163-167.

4. Simons JP, Branstetter BF $4^{\text {th }}$, Mandell DL: Bilateral peritonsillar abscesses: case report and literature review. Am J Otolaryngol 2006; 27: 443-445.

5. Grahne B: Abscess tonsillectomy: seven hundred twenty-five cases. AMA Arch Otolaryngol 1958; 68: 332-336.

6. Lehnerdt G, Senska K, Fischer M et al.: Bilateral peritonsillar abscesses. Eur Arch Otorhinolaryngol 2005; 262: 573-575.

7. Ong YK, Goh YH, Lee YL: Peritonsillar infections: local experience. Singapore Med J 2004; 45: 105-109.

8. Bonding P: Tonsillectomy à chaud. J Laryngol Otol 1973; 87: 1171-1182.

9. Dalton RE, Abedi E, Sismanis A: Bilateral peritonsillar abscesses and quinsy tonsillectomy. J Natl Med Assoc 1985; 77: 807-812.

10. Kieff DA, Bhattacharyya N, Siegel NS et al.: Selection of antibiotics after incision and drainage of peritonsillar abscesses. Otolaryngol Head Neck Surg 1999; 120: 57-61.

11. AlAwadh I, Aldrees T, AlQaryan S et al.: Bilateral peritonsillar abscess: a case report and pertinent literature review. Int J Surg Case Rep 2017; 36: 34-37. 